Research Article

\title{
The surgical management of phylloides tumour
}

\author{
Ashok Suryabhanji Gajbhiye*, Ambrish Somkuwar, Avinash Bokde, Vaibhav Nasare, \\ Kishor Jehughale, Ankit Agrawal
}

Department of Surgery, IGGMC, NAGPUR-18,Maharashtra, India

Received: 07 April 2016

Accepted: 10 May 2016

\section{*Correspondence:}

Dr. Ashok Suryabhanji Gajbhiye,

E-mail: gsashok1972@gmail.com

Copyright: () the author(s), publisher and licensee Medip Academy. This is an open-access article distributed under the terms of the Creative Commons Attribution Non-Commercial License, which permits unrestricted non-commercial use, distribution, and reproduction in any medium, provided the original work is properly cited.

\begin{abstract}
Background: To study clinical presentation and management of this rare disease. Phylloides tumours are rare fibroepithelial lesions of breast.

Methods: A prospective study was conducted in the department of surgery in a medical college and hospital in central India over a period from March 2006 to March 2016. Total 96 female patients of phylloides tumour were included in this study.

Results: Out of 98 patients, majority of patients were in the age group of 31 - 40 years. Mean age of presentation was 37 years ranging from 12 years to 57 years. $43.75 \%$ patients were having breast lump involving all four quadrant of breast. The surgical management includes wide local excision in 28 , lumpectomy in 26 , simple mastectomy in 40 and radical mastectomy in 02 patient. Three histotypes of phylloides tumor, i.e., benign (42 cases, 43.75\%), borderline (12 cases, $12.5 \%$ ), and malignant (42 cases, $43.75 \%$ ) were observed in the present study.

Conclusions: The preoperative diagnosis and proper management are crucial in phylloides tumours because of their tendency to recur and malignant potential in some of these tumours. Excision of the phylloides tumour with a wide margin of healthy tissue is safe and effective method of local control.
\end{abstract}

Keywords: Phylloides, Cystosarcoma, Mastectomy

\section{INTRODUCTION}

In the year 1838 Johannes Muller described a tumour of the breast in young women where the mass would assume a very large dimension with streching of overlying skin and dilated prominent veins. ${ }^{1}$ He named it cystosarcoma phyllode to characterise some important features like cyst or cleft like spaces within the mass along with a leaf or fond like pattern of the stromal elements. Since then sixty two different names have been ascribed to this soft tissue tumour, sometimes known by the eponym " Mullers tumour". Today, WHO recognises it as "phylloids tumours". The words "phylloides" is derived from latin phyllodium and greek phullodes meaning leaf like. Unlike carcinoma breast, phylloides tumors start outside of the ducts and lobules, in the breast's connective tissue, called the stroma which includes the fatty tissue and ligaments that surround the ducts, lobules, and blood and lymph vessels in the breast. In addition to stromal cells, phylloides tumors can also contain cells from the ducts and lobules.

It usually presents as a rapidly growing but clinically benign breast lump. In some patients a lesion may have been apparent for several years, with clinical presentation precipitated by a sudden increase in size. ${ }^{2,3}$ The skin over large tumors may have dilated veins and a blue discoloration but nipple retraction is rare. Fixation to skin and pectoralis muscles has been reported, but ulceration is uncommon. More commonly found in upper outer quadrant with an equal propensity to occur in either breast. Rarely presentation may be bilateral. The median size of phylloides tumors is around $4 \mathrm{~cm}$. $20 \%$ of tumors grow larger than $10 \mathrm{~cm}$. These tumors can reach 
sizes up to $40 \mathrm{~cm}$ in diameter . A significant proportion of patients have history of fibroadenoma and in a minority these have been multiple. Palpable axillary lymphadenopathy can be identified in up to $10-15 \%$ of patients but $<1 \%$ had pathological positive nodes. Macroscopically most small tumors have a uniform white consistency with a lobulated surface, similar to that of a fibroadenoma. Large tumors on cut section often have a red or grey "meaty" consistency with fibrogelatinous, hemorrhagic, and necrotic areas with leaf like protrusions into the cystic spaces. The cytological diagnosis of phylloides tumors is mainly suggested by the presence of hypercellular stroma and the stromal elements on the smears being more numerous than the epithelial ones. The cells on the smears were classified by Deen et al in 1999, and Jayaram and Sthaneshwar in 2002 by comparison with small lymphocytes, in (1) short, round/oval cells, two-size smaller than the size of a lymphocyte: considered to be epithelial cells; (2) long, spindle cells, three-size larger than the size of a lymphocyte: considered to be stromal cells.,

Phylloides is well known for its high potential for local recurrence. In order to decrease the local recurrence, many surgeons have devised a radical surgical approach. There is some disagreement among experts about the with of margin needed, one or two centimeters for reducing the risk of local recurrence. Many authors regard a two centimeters gross margin as safe.

Present prospective study is conducted in the patients attending Surgery out patient department and admitted to surgery wards with cystosarcoma phylloides.

\section{METHODS}

A prospective study was conducted in the department of surgery in a medical college and hospital in central India over a period from March 2006 to March 2016. Total 96 female patients of phylloides tumour were included in this study. Patients with obvious clinical features and other histopathological malignancies were excluded from this study. A detailed clinical history and examination of breast lump was done. Patients were advised fine needle aspiration cytology.

Table 1: Criteria used to classify histological type as proposed by Azzopardi.

\begin{tabular}{|lll|l|}
\hline Criteria & Benign & Borderline & Malignant \\
\hline Tumour margins & Pushing & - & Infiltrative \\
\hline Stroma cellularity & Low & Moderate & High \\
\hline $\begin{array}{l}\text { Mitotic rate (per } \\
10 \text { hpf) }\end{array}$ & $<4$ & $4-9$ & $>10$ \\
\hline Pleomorphism & Mild & Moderate & Severe \\
\hline
\end{tabular}

hpf $=$ high powered field

The famous breast pathologist, Azopardi has described three categories of phylloides tumour based on grade of differentiation as given in Table $1 .^{6}$ The profile photograph of phylloides tumour as shown in Figure 1, 2, 3.

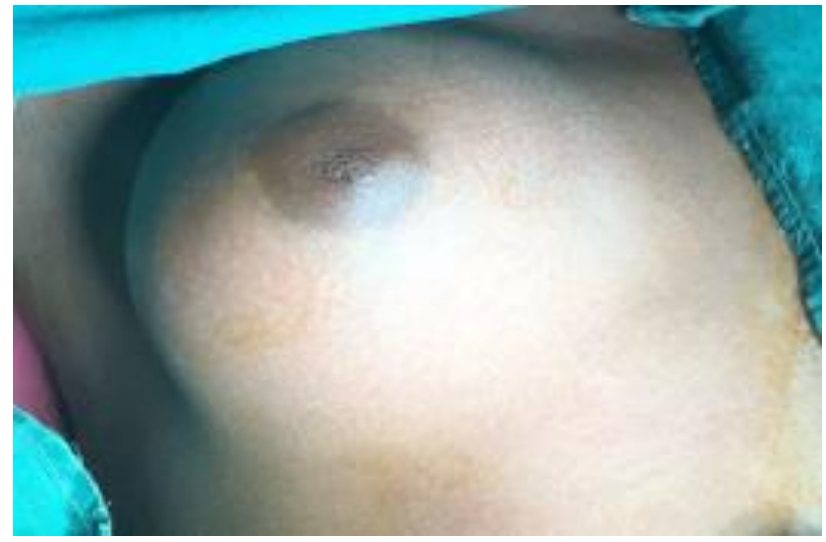

Figure 1: Phylloides tumours of right breast.

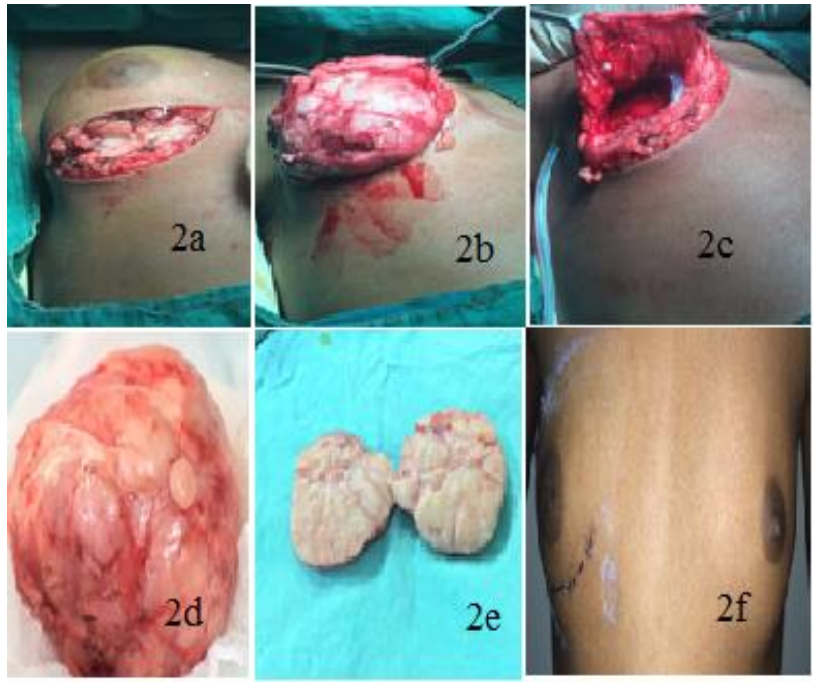

Figure 2: Wide local excision of phylloides tumor.

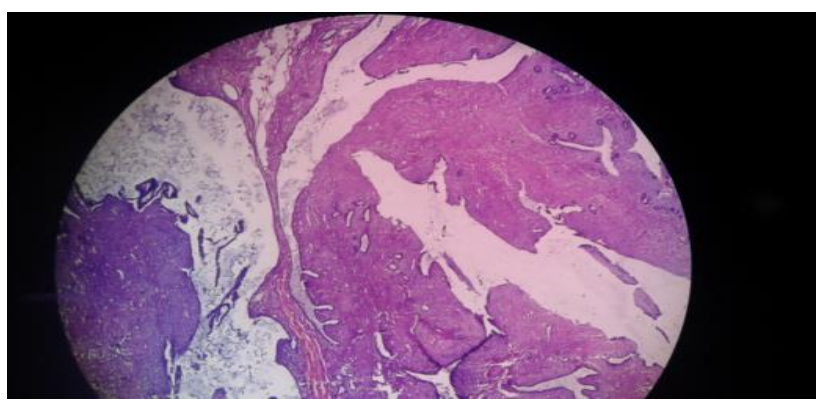

Figure 3: Microscopic view of phylloides tumourclefts and myxoid cellular stroma.

\section{RESULTS}

In the time period between 2006 and 2016, 96 women patients were presented in our institue with clinical, radiological or histopathological diagnosis of phylloides tumour. All of them were operated and confirmed on the histological examination. Majority of patient were in the 
age group of 31-40 years as shown in Table 2. Mean age of presentation was 37 years ranging from 12 years to 57 years. No patients were seen below ten years and above sixty years in the present study.

Table 2: Age wise distribution.

\begin{tabular}{|ll|}
\hline Age (years) & No of patients \\
\hline $11-20$ & 02 \\
\hline $21-30$ & 26 \\
\hline $31-40$ & 55 \\
\hline $41-50$ & 10 \\
\hline $51-60$ & 03 \\
\hline Total & $\mathbf{9 6}$ \\
\hline
\end{tabular}

The main complaint among these women was a palpable painless mass of the breast. Patients were broadly divided under three groups depending on their presentation such as breast lump, breast pain, and pain in ipsilateral axilla as given in Table 3 .

Table 3: Different types of mode of presentations and their incidence.

\begin{tabular}{|lll|}
\hline Presentations & No. of patients & $\begin{array}{l}\text { Percentage } \\
\text { Breast lump only }\end{array}$ \\
\hline Breast lump + Pain & 13 & $85.41 \%$ \\
\hline $\begin{array}{l}\text { Breast lump + Pain in } \\
\text { ipsilateral axilla }\end{array}$ & 01 & $13.55 \%$ \\
\hline Total & $\mathbf{9 6}$ & $1.04 \%$ \\
\hline
\end{tabular}

Majority of patient presented with breast lump accounting $85.41 \%$.Lump in breast was associated pain in 13 patients, while one patient mentioned tenderness of the respective axilla. Out of 96 patient, 51 patient were having breast lump in left breast while remaining 45 patient were having lump in right breast as shown in Table 4. Pain was cyclical in 8 patients and it was non clinical in 5 patients. Bilateral lump was not observed in present series.

Table 4: Number of the patient with Side of breast involvement.

\begin{tabular}{|lll|}
\hline Side involved & No. of patients & Percent $(\%)$ \\
\hline Left & 51 & 53.12 \\
\hline Right & 45 & 46.88 \\
\hline Total & $\mathbf{9 6}$ & $\mathbf{1 0 0}$ \\
\hline
\end{tabular}

Majority of patient were having breast lump involving all four quadrant of breast as given in Table 5. The clinical examination revealed a solitary mobile lesion in all the patients, measuring between 3-16 cm. 91 patients presented with dilated veins of the overlying skin and in one patient bluish discoloration of the skin of the breast above the tumour was present. A palpable mass of the respective axillary region was observed in two women.
Table 5: Distribution of patients with quadrant of breast involvement.

\begin{tabular}{|lll|}
\hline Quadrant & No. of Patients & Percent \\
\hline Upper Outer & 15 & 15.62 \\
\hline Upper Inner & 12 & 12.5 \\
\hline Lower Outer & 4 & 4.17 \\
\hline Lower Inner & 2 & 2.08 \\
\hline Central & 3 & 3.13 \\
\hline $\begin{array}{l}\text { Two or three } \\
\text { quadrant }\end{array}$ & 18 & 18.75 \\
\hline All quadrant & 42 & 43.75 \\
\hline Total & $\mathbf{9 6}$ & $\mathbf{1 0 0}$ \\
\hline
\end{tabular}

On the basis of the criteria proposed by Azzopardi and salvadori et al, including estimation of tumour margin, growth of the connective tissue component, mitoses, and cellular atypia, the entire series was divided into three histotypes as shown in Table- 6 of phylloides tumor, i.e., benign (42 cases, $43.75 \%$ ), borderline (12 cases, $12.5 \%$ ), and malignant (42 cases, $43.75 \%$ ).

Table 6: Type of surgery by histotype of the tumor.

\begin{tabular}{|lllll|}
\hline $\begin{array}{l}\text { Type of } \\
\text { surgery }\end{array}$ & Benign & Borderline & Malignant & Total \\
\hline $\begin{array}{l}\text { Wide local } \\
\text { excision }\end{array}$ & 20 & 06 & 00 & 26 \\
\hline Lumpectomy & 21 & 06 & 01 & 28 \\
\hline $\begin{array}{l}\text { Simple } \\
\text { mastectomy }\end{array}$ & 09 & 05 & 26 & 40 \\
\hline $\begin{array}{l}\text { Radical } \\
\text { mastectomy }\end{array}$ & nil & nil & 02 & 02 \\
\hline Total & $\mathbf{5 0}$ & $\mathbf{1 7}$ & $\mathbf{2 9}$ & $\mathbf{9 6}$ \\
\hline
\end{tabular}

All patients were subjected to surgical management. Modality of treatment available for surgical management of phylloides tumor includes wide local excision, lumpectomy, simple mastectomy and radical mastectomy. 50 patient were found to be benign on histopathology out of which 20 were subjected to wide local excision, lumpectomy done in 21 cases and in remaining 9 cases simple mastectomy were performed. 17 patient were found to be borderline on histopathology, out of which 06 were subjected to wide local excision, lumpectomy done in 06 cases and in remaining 1 case simple mastectomy were performed. 29 patients were malignant on histopathology. Lumpectomy was done in one patient, simple mastectomy was done in 26 patient and remaining two cases were subjected to radical mastectomy.

\section{DISCUSSION}

Phylloides tumour is a fibroepithelial tumour unique to the breast. It is a mixed tumour of epithelial and mesenchymal origin. The tumour lacks a true capsule and is characterized by infiltrative borders. A pseudocapsule of compressed surrounding normal tissue contain microscopic projections of tumour cells, hence more 
tissue is required to be removed in the margin to obtain histological one centimeter margins. ${ }^{7}$ A long history of a lump and the finding of possible remnants of fibroadenoma imply development of cystosarcoma phylloides from fibroadenoma in some cases, in other cases the tumour appears to arise spontaneously. Although aptly named by Johannes Muller on morphological appearance this title is generally considered unsatisfactory. ${ }^{8,9}$

Cysts are not always present and the majority of these tumours have an entirely benign clinical course following complete excision, inspite of some histological features of malignancy. Likewise the commonly used alternative term giant fibroadenoma is unsatisfactory as cystosarcoma phylloides is distinguished from fibroadenoma by an increased stromal cellularity, pleomorphism and mitotic activity.

The average age of women with cystosarcoma phylloides is some 10 to 20 years older than the average women with fibroadenomas, although there is a wide age range for both breast tumours. ${ }^{10}$ Unlike fibroadenomas, cystosarcoma phylloides tend to recur following simple enucleation. In the present study, we came across 96 patients of phylloides tumour. Maximum distribution of cases is in 31-40 years of age group. Indian reports show a wide variation in incidence of phylloides tumour from $0.63 \%$ to $13.8 \% .^{11}$

The study by Aslam reported phylloides tumour to be $1.2 \%$ of all the breast lesions and having peak incidence in pre-menopausal age group. ${ }^{12}$ Phylloides tumour represented 3 patients $(0.7 \%)$ of all lesions in the study of Kumar $\mathrm{M}$ and $0.65 \%$ by Akhator et al. ${ }^{13,14} \mathrm{~A}$ study was conducted by $\mathrm{H} \mathrm{C}$ Umpleby et al and their median age was 47 years (range 18-71Years). Department of Surgery at Tokyo, Japan conducted a study on recurrence of benign breast conditions after surgery and found rate of recurrence for phylloides tumour to be 50\%. ${ }^{15}$ Average age of the patients found in the present study is 37 years. No case of recurrence was seen in our study until now.

Majority of patient presented with breast lump only accounting for $85.41 \% .13$ patients presented pain in the breast region in addition to the lump, while one patient mentioned tenderness of the respective axilla along with the lump. According to Iyer and Gore fibroadenoma and fibroadenosis are seen as diseases of younger age group (age <30 years) and phylloides tumours are seen in older age group. ${ }^{16}$ The main symptom patients presented with was lump in the breast. The lump was seen in cent percentage of patients with cystosarcoma phylloides as seen in their study.

Most authors assume that phylloides tumours includes three distinct histotypes: benign, borderline and malignant, although the criteria for this distinction are poorly defined and several classifications have been proposed. According to WHO, it is considered useful to differentiate cases of hylloides tumours by the following criteria: frequency of mitoses, infiltrative margins, cellular atypia, and cellularity. Nevertheless, lack of standard interpretation of histologic features is one of the reasons why the balance between benign, borderline and malignant phylloides tumours is different in various series. The incidence of histologically malignant phylloides tumours ranges widely from $1.9 \%$ to $48.9 \%$. In this series following above criteria histotypes of phylloides tumor, was found to be resembling the interpretation of Inoshita, Bennett et al and Marian Reinfuss el al. i.e. benign (42 cases, $43.75 \%$ ), borderline (12 cases, $12.5 \%$ ), and malignant (42 cases, $43.75 \%$ ).

Badwe RA et al recently developed new innovation on surgical resection of phylloides tumour. ${ }^{17}$ Since most patients in Asia present with very large breast tumours with close proximity to the skin and pectoralis major, a three dimensional en block removal of the mass with overlying skin and underlying muscles. The wide local excision (for a small mass) and a "radical mastectomy" for large masses should be followed by radiotherapy if the histological features point towards malignancy. Another indication of radiotherapy is a case of recurrent tumour. Adjuvant radiotherapy in a multicenter study of 46 patients has been found to reduce the risk of local recurrence to zero as reported by Barth et al.

Twenty percent of tumors grow larger than $10 \mathrm{~cm}$, the arbitrary cutoff point for the designation as giant phylloides tumor, an entity that presents the surgeon with several unique management problems. These tumors can reach sizes up to $40 \mathrm{~cm}$ in diameter. ${ }^{2}$ Since an excision with the required margins is often impossible in giant phylloides tumors, mastectomy should be reserved for larger tumors and should be considered in recurrent tumors, especially of the malignant histotype. ${ }^{18-21}$ Local recurrence in phylloides tumors has been associated with inadequate local excision and various histological characteristics, including mitotic activity, tumor margin, and stromal cellular atypia.

Depending on the size of the breast and the location of the phylloides tumour, mastectomy may also be required for tumors that are between 5 and $10 \mathrm{~cm}$ in diameter. ${ }^{22}$ While managing a giant phylloides tumor, emphasis should be on complete extirpation of all visible tumors and breast tissue during mastectomy to minimize the chances of recurrence. As malignant phylloides tumors undergo mainly hematogenous spread, the proportion of patients with lymph node metastases are <1\% (lymph node enlargement in about $10 \%$ ) and routine axillary clearance is not recommended. Axillary dissection is required, when histologically positive for malignant cells. Chest wall invasion appears to be an uncommon event with phylloides tumors, extended excision of involved pectoralis muscle, followed by reconstruction of the chest wall with marlex mesh or latissimus dorsi muscular/myocutaneous flap been recommended if the fascia or muscle is infiltrated. ${ }^{2}$ 
Local recurrence rates for phylloides tumors are 15 to $20 \%$ and are correlated with positive excision margins, rather than with tumor grade or size. ${ }^{1,23-25}$ Other studies have shown a higher risk of local recurrence in borderline and malignant tumors.

In a series of 21 patients by Salvadori et al 51 patients were treated with breast conserving surgery (enucleations, wide excisions) and 14 of the tumors recurred locally. In contrast, the 20 patients treated with mastectomy (subcutaneous, modified radical, or radical) showed no evidence of local recurrence. ${ }^{26}$ Importantly, there is no contraindication to immediate reconstruction after mastectomy in cases of giant phylloides tumor, and this decision can be made solely based upon patient preference. $^{27,28}$

In the present study 50 patient were found to be benign on histopathology out of which 20 were subjected to wide local excision, lumpectomy done in 21 cases and in remaining 9 cases simple mastectomy were performed. 17 patient were found to be borderline on histopathology out of which 06 were subjected to wide local excision, lumpectomy done in 06 cases and in remaining one patient simple mastectomy were performed. 29 patient were malignant on histopathology. Lumpectomy was done in one patient, simple mastectomy was done in 26 patient and remaining two cases were subjected to radical mastectomy. The adjuvant radiotherapy may be effective in reducing the risk of local recurrence.

On axillary sonography suspicious or palpable node should be subjected to needle aspiration. A positive node for metastasis would necessiatate an axillary lymph node dissection followed by chemotherapy and radiotherapy. Metastasis are always from the mesenchymal element; hence they behave like a "pure sarcoma". The following drugs have been described to be effective for malignant phylloides: ifosfamide, cisplatin and etoposide. ${ }^{29,30}$

\section{CONCLUSION}

The preoperative diagnosis and proper management are crucial in phylloides tumours because of their tendency to recur and malignant potential in some of these tumours. Excision of the cystosarcoma phylloid with a wide margin of healthy tissue is safe and effective method of local control .The adjuvant radiotherapy is effective in reducing the risk of local recurrence. A positive axillary lymph node enlargement would necessitate an axillary lymph node dissection followed by chemotherapy and radiotherapy.

\section{Funding: No funding sources} Conflict of interest: None declared

Ethical approval: The study was approved by the institutional ethics committee

\section{REFERENCES}

1. Muller J. Uber den feinern bau und die formen der krankhaften geschwulste. Vol. 1. Berlin, Germany: Reimer; 1838:54-60.

2. Reinfuss M, Mitus J, Duda K, Stelmach A, Rys J, Smolak K. The treatment and prognosis of patients with phylloides tumor of the breast: an analysis of 170 cases. Cancer. 1996;77:910-6.

3. Chua CL, Thomas A, Ng BK. Cystosarcoma phylloides: a review of surgical options. Surgery. 1989;105(2):141-7.

4. Deen SA, McKee GT, Kissin MW. Differential cytologic features of fibroepithelial lesions of the breast. Diagnostic Cytopathology. 1999;20:53-6.

5. Jayaram G, Sthaneshwar P. Fine-needle aspiration cytology of phylloides tumors. Diagnostic Cytopathology. 2002;26(4):222-7.

6. Azzopardi JG. Problems in breast pathology. In: Bennington $\mathrm{J}(\mathrm{ed})$ Major progress in pathology. W.B.Saunders, Philadelhia; 1979:346-365.

7. Calhoun KE, Lawton TJ, Kim JN. Phylloides tumours. In : Harris JR, Lippman ME, Morrow M, Osbome CK (eds) Diseases of the breast, 4th eds. Lippincott Williams \& Wilkins, Philadelphia; 2010:781-792.

8. Ridgway PF, Jacklin RK, ZiprinP. Perioperative diagnosis of cystosarcoma phylloides of the breast may be enhanced by MIB-1 index. Journal of Surgical Research. 2004;122(1):83-8.

9. El-Naggar AK, Mackay B, Sneige N, Batsakis JG. Stromal of the breast: a comparative flow cytometric study. Journal of Surgical Oncology. 1990;44(3):151-6.

10. Jacklin RK, Ridgway PF, Ziprin P, Healy V, Hadjiminas D, Darzi A. Optimising preoperative diagnosis in phylloides tumour of the breast. Journal of Clinical Pathology. 2006;59(5):454-9.

11. Khanna S, Arya NC, Khanna NN. Spectrum of benign breast disease. Indian Journal of Surgery 1988; 50:169-75.

12. Aslam HM, Saleem S, Shaikh HA, Shahid N, Mughal A, Umah R. Clinico-pathological profile of patients with breast diseases. Diagnostic pathology. 2013;8(1):77.

13. Kumar M, Ray K, Harode S, WaghDD. The Pattern of Benign Breast Diseases in Rural Hospital in India East and Central African Journal of Surgery. 2010;15(2):59-64.

14. Akhator A. Benign Breast Masses in Nigeria. Nieg Jr of Surg Sciences. 2007;17:105-8.

15. Enmoto K, Fujiwara K, Masa Nura S, Teramoto H, Sato H, Utsumi J, et al. Follow up study of benign breast diseases. Journal of Japan Surgical Society Sept. 1989;90(9):1403-5.

16. Iyer S P, Gore M. Epidemiology of Benign Breast Diseases in Females Of Childbearing Age Group. Bombay hospital Journal. 2000. Original research/ bhj.org online article. 
17. Badwe RA, Kataria K, Srivastava A. Surgical Resection of Phylloides Tumour: a Radical Approach as a Safegaurd Against Local Recurrence. Indian J Surg. 2015;77(2):161-3.

18. Parker SJ, Harries SA. Phylloid tumour. Postgrad Med J. 2001:77:428-35.

19. Norris HJ, Taylor HB. Relationship of histologic features to behavior of cystosarcoma phylloides. Analysis of ninety-four cases. Cancer. 1967;20(12):2090-9.

20. Contarini O, Urdaneta LF, Hagan W, Stephenson SE. Cystosarcoma phylloides of the breast: a new therapeutic proposal. American Surgeon. 1982;48(4):157-66.

21. Baker RR. Unusual lesions and their management. Surgical Clinics of North America. 1990;70(4):96375.

22. Singh G, Sharma RK. Immediate breast reconstruction for phylloides tumors. Breast. 2008;17(3):296-301.

23. Rowell MD, Perry RR, Hsiu JG, Barranco SC. Phylloides tumors. The American Journal of Surgery. 1993;165(3):376-9.

24. Mangi AA, Smith BL, Gadd MA, Tanabe KK, Ott MJ, Souba WW. Surgical management of phylloides tumors. Archives of Surgery. 1999;134(5):487-93.
25. Khanna S, Gupta S, Khanna NN. Sarcomasof the breast:homogenous or heterogenous. Journal of Surgical Oncology. 1981;18(2):119-28.

26. Salvadori B, Cusumano F, Del Bo, Delledonne V, Grassi M, Rovini DR, et al. Surgical treatment of phylloides tumors of the breast. Cancer. 1989;63(12):2532-6.

27. Mendel MA, De Palma RG, Vogt C, Reagan JW. Cystosarcoma phylloides: treatment by subcutaneous mastectomy with immediate prosthetic implantation. The American Journal of Surgery. 1972;23:718-21.

28. Orenstein A, Tsur H. Cystosarcoma phylloides treated by excision and immediate reconstruction with silicon implant. Annals of Plastic Surgery. 1987;18(6):520-3.

29. Barth RJ, Wells WA, Mitchell SE, Cole BF. A prospective multi institutional study of adjuvant radiotherapy after resection of malignant phylloides tumours. Ann Sueg Oncol.2009:16(8):2288-94.

30. Liang MI, Ramaswamy B, Patterson CC, McKelvey MT, Gordillo G, Nuovo GJ, et al. Giant breast tumors: surgical management of phylloides tumors, potential for reconstructive surgery and a review of literature. World Journal of Surgical Oncology. 2008;6:117.

Cite this article as: Gajbhiye AS, Somkuwar A, Bokde A, Nasare V, Jehughale K, Agrawal A. The surgical management of phylloides tumour. Int Surg J 2016;3:1420-5. 